INVITED 2009 CARROLL

D. Clark Lecturer

AT THE

UNIVERSITY OF KANSAS 



\title{
INTERVIEW WITH
}

\section{ANNETTE LAREAU}

\author{
InTERVIEW CONDUCTEd By: \\ PoOya NADERI (University of Kansas) \\ Carrie Wendel-Hummell (University of Kansas)
}

\author{
Interview Prepared By: \\ Annette Lareau (University of Pennsylvania) (editor) \\ M. Katherine Mooney (editorial assistance) \\ JILLIAN WANG (TRANSCRIPTION)
}

\begin{abstract}
Annette Lareau is the Stanley I. Sheerr Professor in the Department of Sociology at the University of Pennsylvania. She is the author of Unequal Childhoods: Class, Race, and Family Life (University of California Press). Unequal Childhoods won the best book award from three sections of the American Sociological Association: Sociology of the Family, Sociology of Children and Youth, and Sociology of Culture (co-winner).
\end{abstract}

WENDEL-HUMMELL: Let's begin with the evolution of your research interests over time. Tell us how you came to write the book Unequal Childhoods. ${ }^{1}$

LAREAU: I started graduate school in 1976. At that time, there was a very significant correlation between family background and achievement, but how it happened was considered to be a black box. Jerome Karabel and A.H. Halsey provide an excellent, 77page introduction to their edited collection, Power and Ideology in Education. ${ }^{2}$ They show how the questions that interest researchers

\footnotetext{
${ }^{1}$ Lareau, Annette. [2003] 2011. Unequal Childhoods: Class, Race, and Family Life. $2^{\text {nd }}$ ed. Berkeley, CA: University of California Press.

${ }^{2}$ Karabel, Jerome and A. H. Halsey, eds. 1977. "Introduction: Educational Research: A Review and Interpretation." In Power and Ideology in Education. New York: Oxford University Press.
} 
are historically specific and contingent on broader social conditions. I think sociologists often downplay those issues, and focus, in some ways, on their own individual interests.

In any event, I was interested in understanding what was going on in families and schools, and I was frustrated by the tendency for people to look either at schools, on the one hand, or to look at families, on the other hand. I was interested in the interactions between these institutions. So, in my dissertation (which eventually became Home Advantage, ${ }^{3}$ my first book), I looked at class differences in white parents' involvement in their children's schooling. I found that working-class parents turned over responsibility to the school and that middle-class parents intervened in school. But when I finished that project, I wasn't quite sure whether those patterns were connected to the fact that the parents were interacting with professionals (teachers). So I thought, "What if I were to look at Little League? Would the patterns be different?" And that's how I stumbled into the study that ultimately became Unequal Childhoods.

I did interviews with families involved in organized sports. The interviews weren't that revealing or that rich. When I had interviewed moms about schools, they could talk at great length about the teacher, and the homework, and this and that. But it was different when I interviewed people about soccer. Soccer is very disruptive; there are practices twice a week, there are rainouts, there are multiple games, families may have multiple kids on different teams. It really takes over dinner time; it takes over many aspects of family life.

But people I interviewed were not particularly reflective, or they didn't give long, detailed, rich answers. They said, "Well, he brought home the form, and I wanted him to play, so I said, 'Okay.' " And I said, "Well, could you tell me more about that?" They said, "Oh. Well, it teaches them discipline," or, "He likes it." So, I felt that the interviews weren't teaching me what I wanted to learn. I felt like I had to begin to think about the idea of observing families.

${ }^{3}$ Lareau, Annette. [1989] 2000. Home Advantage: Social Class and Parental Intervention in Elementary Education. Lanham, MD: Rowman and Littlefield Publishers, Inc. 
That seemed very intimidating and difficult at that time. Nobody had really done it in the way I was beginning to think about. I was teaching at a university in the Midwest. In the community I call Lawrenceville, there was a mom I liked and who liked me. I asked her, with some trepidation, "Could I watch you and your kids one afternoon?"

The daughter had never met me, but the son had. The day of the observation, the girl was chewing out her brother for making her late. They were having a spat despite a stranger's presence. So that made me feel like it would be possible to observe families and see ongoing social life.

WENDEL-HUMMELL: What about your most recent work? You seem to be going in a new direction, away from child rearing.

LAREAU: I'm really interested in the transmission of advantage in American society. And I am still interested in how parents' resources have an impact on their children. I'm interested in what schools children end up in; I'm interested in how big their homes are and whether or not they have their own bedrooms. I'm interested in the standards of living that children have across different types of families. Unequal Childhoods was more about the interior of the home and how people scold children, or hush children, or get children to get ready to go out. It was really focused on those sorts of micro-interactions. Now, I'm interested in looking at wealth and wealth transfers, and at people's decisions about what school district to be in, and at how they situate their children to ensure that they are positioned to have other advantages and experiences. So, I'm still interested in children and in children's life-chances, but I'm looking at these subjects in a different way.

NADERI: You frequently address gender and race in your work. Let's start with gender. I am curious as to what role men and fathers play. Have you found notable trends in value commitments in child rearing that you could elaborate on here?

LAREAU: This is a good question. I think reasonable people disagree about how to understand the trends. There's been a huge increase in men's participation in family life. They're spending 
more time doing housework; they're spending more time interacting with kids. I think Changing Rhythms of American Family Life, ${ }^{4}$ the book by Suzanne Bianchi, John Robinson and Melissa Milkie, really highlights that change. Moms are spending less time doing housework and they're spending more time interacting with kids. So, there's been a rise of what could be called "intensive parenting." But even with fathers' increased participation in family life, there remains a huge gap by gender. Of course, it depends on how you measure participation. If you combine men's labor force participation and their household and family obligations, and compare that to women's labor force participation and their household and family obligations, then the gender gap is much smaller. If you look just at men's actions within the home, the gap is much larger. And this is particularly the case for men's contribution to the whole work of family life, including planning kids' schedules and coordinating daily activities. I wrote a paper called "Where Families and Children's Activities Meet: Gender, MESHing Work, and Family Myths" with Pat Berhau and Julie Press. ${ }^{5}$ We examine the mental, emotional, social, and physical work that goes into planning children's organized activities. And it's quite a lot of work.

When I did the research for Unequal Childhoods, I spent a lot of time and money interviewing dads. Every dad I could find, I interviewed. And the interviews didn't go that well. Dads were very important people in their children's lives. Children adored their dads, when the kids were nine or ten. When dads came home, they joked with kids, they played with kids. But dads knew very little information about their children's organized activities, and dads did not initiate or take responsibility for the children's schoolwork the way moms did. What I found was very consistent with all the literature. So here I was, asking dads these questions, and the interviews weren't going that well. I analyzed the problems of studying dads in a paper called "My Wife Can Tell Me Who I

\footnotetext{
${ }^{4}$ Bianchi, Suzanne, John Robinson, and Melissa Milkie. 2006. Changing Rhythms of American Family Life. New York: Russell Sage Foundation. ${ }^{5}$ Behau, Patricia, Annette Lareau, and Julie E. Press. 2011. "Managing Children's Activities: Implications for the Gender Division of Household Labor. Pp. 4360 in Anita Garey and Karen Hansen, eds. At the Heart of Work and Family: Engaging the Concepts of Arlie Russell Hochschild. New Brunswick, NJ: Rutgers University Press.
} 
Know."' I gave one dad a list of the kids in his child's classroom and said, "In the grocery store, who would you recognize and say 'Hello' to?" He said, "Well, you know, my wife can tell me who I know." He saw his wife's knowledge as heavily interdependent with his knowledge.

Overall, men's roles remained a bit of an enigma. The observations showed that dads were very important in the home. But the interviews, although they were not a total and complete waste of time, were not that helpful. I think that, especially when you're talking about invisible labor--the management and the initiation work--it's the moms who do it. There's a hilarious YouTube clip called "The Mom Song." It is set to the William Tell Overture. In 2 minutes and 55 seconds, singing, Anita Renfro says all the reminders she does in a day: "Get up, brush your teeth," "Don't roll your eyes at me," "You're grounded till you're 36." [Laughter.] You know, the things moms say over and over again. Moms remind kids. And there are some exceptional dads who do this. When moms do shift work and they're gone, then dads are more likely to do this. But, in general, the gender division of labor remains very powerful.

NADERI: Great. Now, could you speak to the race-class nexus? Some argue that race isn't a proxy for class. So I am curious about how, in your work, you go about extricating race from class and dealing with that tension.

LAREAU: For Unequal Childhoods, a critical factor was the fact that I had 36 middle-class parents. I had 18 black middle-class families. That was a lot. They were a hard group to find and to interview. Now we have a growth in the literature: Karyn Lacy's book, Blue-Chip Black; ${ }^{7}$ Mary Pattillo's work, Black on the Block and Black Picket Fences; ${ }^{8}$ Bart Landry's research on race, gender, and stratification, The New Black Middle Class. ${ }^{9}$ The literature

${ }^{6}$ Pp. 409-433 in Qualitative Sociology 26. (2003).

${ }^{7}$ Lacy, Karyn R. 2007. Blue-Chip Black: Race, Class, and Status in the New Black Middle Class. Berkeley, CA:University of California Press.

${ }^{8}$ Pattillo, Mary. 2007. Black on the Block: The Politics of Race and Class in the City. Chicago, IL: University of Chicago Press.

Patillo-McCoy, Mary. 1999. Black Picket Fences: Privilege and Peril Among the Black Middle Class. Chicago, IL: University of Chicago Press.

${ }^{9}$ Landry, Bart. 1987. The New Black Middle Class. Berkeley, CA: University of 
on the black middle class had been thin for a long time. Jessica Vasquez, in your own department, is doing a book on middle-class Hispanics. ${ }^{10}$ So I think this is one of the holes in the literature which is gradually getting filled.

In the interviews for Unequal Childhoods, I looked very hard for evidence of differences between my middle-class whites and blacks. I went over the transcripts, and I looked over the observations. I kept looking for what I would call "race-based patterns." There were some things that I felt were present in the homes - in the Marshall family, for example - sort of celebrating African-American history. The kinship system, the churches, also were racially separating. So, it wasn't that race wasn't there. In my current project, race is extremely powerful. That's because the project is about housing decisions, and neighborhoods are very heavily segregated. Home values in black neighborhoods rise more slowly than those in white neighborhoods. There has been some change but not a lot of change; blacks remain much more segregated than Hispanics and Asians. So, in some ways, my current project is really heavily about race.

I think race is very charged in America. It ended up being one of the most controversial aspects of Unequal Childhoods. When I wrote Unequal Childhoods, I always tried to be clear that people live in racially segregated neighborhoods, dads received insults on the street, and so forth. There are many ways that race is very important in daily life. But in terms of what I was looking at with my relatively small, non-random sample - language use, organized activities, and intervention in institutions - there were very powerful similarities between black and white families of the same class. And there was a huge difference between classes (for example, between the black middle-class boy, Alexander Williams, and say, Harold McAllister, the boy from the poor home, or Tyrec Taylor, who was from a working-class family).

WENDEL-HUMMELL: I'm interested in your thoughts about public sociology. Unequal Childhoods has gotten a fair amount of attention in the popular press. At a very broad level, how does it

California Press.

${ }^{10}$ Vasquez, Jessica. 2011. Mexican Americans across Generations: Immigrant Families, Racial Realities. New York: New York University Press. (forthcoming) 
feel to have your research reach beyond our "ivory towers"?

LAREAU: It's a great honor to have this happen. I tried to write the book to be accessible and readable, but my primary audience was always Introduction to Sociology students. You have to make a lot of decisions when writing a book. There are people I admire who I think tried to write popular books, and the books ended up being vacuous; they didn't have enough heft. So, in the end, I just let go of the idea that I was writing for a popular audience and focused on the Introduction to Sociology audience. I wanted the book to be interesting and readable, but I also tried to have a conversation with graduate students and faculty, using the footnotes.

It has been a real learning experience interacting with journalists and everyday readers. The timeline is different. Often, six months ahead of time, you schedule your courses in a university. You plan talks months ahead of time. Journalists often work on a 24-hour clock. So, they call you up at two o'clock on Tuesday, and the story is due at six o'clock on Thursday, and it's going to run on Friday. So there's this sort of immediacy to it; they really need for you to talk to them, right then. It's a big adjustment. And you also have to let go of having control over the process, because sometimes they use your evidence to advance their thesis - which might not be the same as your thesis. And that, also, is a huge adjustment. Malcolm Gladwell summarized my book in his book Outliers ${ }^{11}$ and did a super job. David Brooks (of The New York Times) wrote a column on the book and in 744 words summarized it without ever using the words "concerted cultivation" and "natural growth." 12 I thought he did a really good summary. But his interpretation of the meaning of the evidence was different than the interpretation that I would have given it.

I do have a piece of advice. Janny Scott from The New York Times came to a conference that I had organized for a book that Dalton Conley and I edited called Social Class: How Does it Work ${ }^{13}$ She

\footnotetext{
${ }^{11}$ Gladwell, Malcolm. Outliers: The Story of Success. 2008. New York: Little, Brown and Company.

${ }^{12}$ Brooks, David. 2008. "Lost in the Crowd." The New York Times, December 15 , p. A37.

${ }^{13}$ Lareau, Annette, and Dalton Conley, eds. 2008. Social Class: How Does It Work? New York: Russell Sage Foundation Publications.
} 
explicitly said that it's very helpful for the reporters at The New York Times and other newspapers when academics write them, call them or email them about work they are doing on a particular subject. She thinks that professors or people who have their degrees or are working in the field should contact reporters. For instance, the researcher would call a reporter and say, "I know that you have written articles on this topic. I thought that you might be interested in some research I have done recently." I was thinking at the time, "This rewards chutzpa." But journalists are on such a tight deadlines that they don't have time to do this themselves. And they don't want your university's press office to do it - they want you, the professor, to do it. Sometimes, when you send articles to a reporter, one person reads the material, and then another person reads it--and this can have a huge impact.

I think sociologists' work is very interesting. I think it's often much more insightful than the work of economists, and yet economists get much more airtime on key media outlets than do sociologists. So, I believe in the notion of public sociology. I think it's important to do.

WENDEL-HUMMELL: Your answer covered a couple of my other questions. I'd like to get back to the David Brooks op-ed piece, though, because he is known as a moderate conservative, and his views often do not align with the sociological perspective. For the most part, he gave your book a fairly nuanced reading and summary. Still, he concluded with the statement, "But the core issue is that today's rich don't exploit the poor, they just outcompete them." 14 Would you expand a bit more about your reaction to the David Brooks piece, and about his concluding statement?

LAREAU: [long pause] You know, I'm a lifelong Democrat. I will always be a Democrat. The conclusion David Brooks drew in the last sentence was not a conclusion I would have drawn. But I think that when you do social science research, people interpret your data differently. We're having a big debate about healthcare now in America, and the facts do not speak for themselvespeople interpret them. That's why we have theory. Functionalists and conflict theorists have different theoretical perspectives; they interpret data in different ways. This is reality. This is the way the

${ }^{14}$ See note 13 . 
world works. You can't control how people are going to interpret your data. You have to do the best you can.

There were people who told me to keep some pieces out of my book because they thought they might reinforce negative stereotypes of poor black children. In particular, in the book there's a description of a fight involving Mrs. McAllister, who's from an African-American home at the poverty level, and her sister. Her sister's on dope and being very difficult; she feels she has to throw her sister out. So, there's quite a bitter conflict. And my mom (who's no longer alive) read it, and she said, "The mother had to do that. She had to make it a home." And so my mom understood the logic of it. But there were people who told me not to publish that, not to include it.

It was a very difficult decision, because of the worry that moderate Republicans or cultural conservatives could look at the cultural practices, misunderstand the argument, and then use it to advance their agenda. But despite that worry, I included that fight. I did my best to try to make it clear what I thought were the structural roots of the problem. But I didn't take it out-something which I think some people might have done. That part was a big worry for me: how people would interpret the book.

Returning to David Brooks, there is sort of an interesting background story. I got an email on a Tuesday, saying that he was planning to write a column for the Thursday paper. I nearly fell off my chair. He said he'd like to talk to me, that he had a couple of questions. It was about seven o'clock at night when we talked. And he wrote the column, I'm sure, on Wednesday, in a couple of hours. I thought it was very impressive how he summarized the book without ever using the key terms [laughs]. I was very impressed by the speed of it. He had read Home Advantage, and he had also read Unequal Childhoods.

He went back to check old issues and told me that Unequal Childhoods had not been reviewed in The New York Times, as if this were a surprise [laughs]. This was not a surprise to me! But he acted as if this was a surprise. But you can tell, journalists often envy sociologists, who are able to spend much more time in the field. Reporters are on such a rapid clock-they can't spend two 
months or two years. They just don't have that kind of time.

WENDEL-HUMMELL: In addition to having your book quoted often and summarized in the popular press, you also wrote some of your own op-eds and did some radio interviews. Is there anything else you would like to say about the lessons you learned in speaking to the public? Do you have any general advice for future sociologists, or for students like myself, who aspire to do some public work?

LAREAU: I'm glad you asked that, because being a public sociologist is not something you learn how to do in graduate school. It's a wonderful idea to write an op-ed. For instance, if you have a paper due to come out in a journal, before the paper appears-but after it has been accepted-you should write an op-ed. Timing really matters in the news world. News has to be new. If something has been published and has been around awhile, it's not new. So there's a timing issue in publicity that turns out to be very important. Major publications also like to have the jump on the story. They like to be first-The New York Times likes to be first. So, I think it's a fabulous idea to write an op-ed, and to tie the op-ed to something that's about to happen: Mother's Day, Father's Day, Christmas, Take a Child to Work Day, the release of labor statistics, healthcare reform. You want to tie an op-ed to an important issue.

And you need to have your thesis clearly stated, usually by the second sentence or the third sentence. It's a little bit like writing poetry, I understand. Every word counts. Six hundred words is not very many words. But that will link people to your other work, and generate interest and generate readers. That's a very valuable thing to do, one that often will lead to something else. I also think it's a good idea to use informal networks, to see if anyone knows anyone who knows a writer. There are people who write for the New Yorker, or for the Atlantic, or for your alumni news magazine, or for the college newsletter. I think if you spend a lot of time doing original research, it makes sense to invest a month or two in trying to create opportunities for people to read it. Every university has a press office. And those people are thrilled to help get the university's name in the newspaper. And that's their job. Also, if you have an article that's about ready to appear, it's good to go see them and 
have them do a press release. They can also interview you. I was at Temple University when Unequal Childhoods was published. I went to the press office, and they did a practice interview with me. And that helped me. Because it turns out that if you're on TV for 30 seconds or a minute, that is a really long time.

If your work is covered in the newspaper or in a magazine, they're more likely to quote more extensively from the work. So, my focus has been on the print media. Also, in today's world, you can create a blog. A blog can be a way to have people learn about your work. But I think it's important to do really good work, and I think that's really the primary thing. Once you have done good work, though, if it's applicable, I think it's worth spending some time-a little bit of time, not a lot of time-sharing the results with the public.

WENDEL-HUMMELL: Good. Is there anything else you'd like to mention?

LAREAU: I have one more thing: It's really important to write clearly. You can't have sentences jammed up with a lot of jargon. Jargon would be very hard for the general public. I think Arlie Hochschild has done a wonderful job with cutting jargon. It is difficult to write clearly. Not writing simply, but clearly. Not dumbing it down--keeping the ideas in the argument intact--but not having the prose convoluted or confused or difficult. Trying to make your writing clear is really the key.

Note: This is an edited version of an interview conducted on October 2, 2009 in the Department of Sociology at the University of Kansas, Lawrence, KS. Some changes to the interview transcript were minor (i.e., smoothing out sentences to improve flow and clarity). In other instances, Annette Lareau added words or phrases to help readers more quickly and easily grasp her meaning. She is grateful to Jillian Wang for her transcription of the interview and to M. Katherine Mooney for editorial assistance. All errors, of course, are the responsibility of Annette Lareau. 